\title{
We Insist! Freedom Now Suite: O Ativismo Político de Max Roach no Movimento de Direitos Civis através do Jazz (Estados Unidos, 1950-1960)
}

\author{
We Insist! Freedom Now Suite: The Max Roach Political \\ Activism in the Civil Rights Movement through the Jazz (Uniited \\ States, 1950-1960)
}

\author{
Edimar Luciano Silva ${ }^{1}$
}

\section{RESUMO}

Ao longo de sua história o jazz projetou-se como uma voz dos afroamericanos e, nos Estados Unidos, a partir do final dos anos 1950, a relação entre este gênero musical e a política se intensificou. O presente estudo elegeu o jazz como objeto e estabeleceu como recorte temporal o período que abrange de final os anos 1950 e 1960, momento de grande efervescência dos movimentos pelos direitos civis nos Estados Unidos, com destaque para a figura do baterista Max Roach e uma de suas obras: We Insist Freedom Now Suite. A partir desta escolha pretendemos compreender a atuação de Max Roach como ativista político e a forma como ele lançou mão da música para inserir-se no movimento dos direitos civis.

Palavras-chave: História Social. Max Roach. Direitos Civis. Jazz.

\section{ABSTRACT}

Alongside its history, Jazz has been projected as a voice of the Afro-Americans, and in the U.S., from the end of the 1950's, the relation between this musical gender and politics has been intensified. This study selected Jazz as its object and established a temporal set that ranges from the end of 1950's and the decade of 1960, a moment of great effervescency in what is related to the Civil Rights movements in the States. In this scenario we highlight the drummer Max Roach and one of its works: "We Insist Freedom Now Suits". From this choice we are eager to comprehend the action of Max Roach as a political activist,

\footnotetext{
${ }^{1}$ Mestre em História Social pela Universidade Estadual de Londrina (UEL) / Brasil.
} 


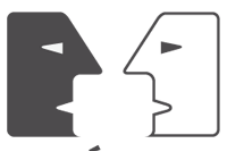

ANTÍTESES

and so the way he handled to engage the Civil Rights claim.

Keyword: Social History. Max Roach. Civil Rights. Jazz. 